Perina Vukša Nahod

\title{
NAGLASNE PARADIGME PRIDJEVA U SLIVANJSKIM GOVORIMA
}

dr. sc. Perina Vukša Nahod, Institut za hrvatski jezik i jezikoslovlje, pvuksa@ihjj.hr, Zagreb

izvorni znanstveni članak

UDK 811.163.42'282(497.5 Slivno)

rukopis primljen: 15. 3. 2017.; prihvaćen za tisak: 30. 4. 2017.

\begin{abstract}
U radu se na temelju vlastita terenskoga istraživanja donosi sinkronijski prikaz naglasnih paradigama pridjeva u slivanjskim govorima Slivna Ravnoga, Mihalja, Blaca i Podgradine u Neretvanskoj krajini, koji su dio istočnohercegovačkoga dijalekta, slivanjsko-zažapskoga govornog tipa. Nadalje, utvrdit će se naglasne varijacije u ostalim, posebice dodirnim, istraženim štokavskim govorima.
\end{abstract}

Ključne riječi: štokavsko narječje; slivanjsko-zažapski govorni tip; pridjevi; naglasne paradigme

\section{Uvod}

Slivno Ravno područje je koje se nalazi u Neretvanskoj krajini s lijeve obale rijeke Neretve. Riječ je o kraju koje zahvaća izrazita depopulacija te u nekim naseljima (od njih 18 koji pripadaju Općini Slivno Ravno) živi tek nekoliko stanovnika. Slivanjski govori ${ }^{1}$ pripadaju štokavskomu narječju, njegovu istočnohercegovačkom dijalektu i slivanjsko-zažapskom govornom tipu. Riječ je o dijalektološki bitnome području koje je predstavljalo granicu novoštokavskoga ikavskog i istočnohercegovačkoga dijalekta, dok se danas zbog različitih migracija može utvrditi da rijeka Neretva ne predstavlja više u literaturi često isticanu granicu.

1 O slivanjskome području i slivanjskim govorima više u Vukša Nahod 2014, a o naglasku imenica $e$-vrste i $i$-vrste u slivanjskim govorima u Vukša Nahod 2015a. 


\section{Metodologija i ciljevi}

U razdoblju od 2011. do 2013. godine terenskim je istraživanjem prikupljena građa u punktovima Slivno Ravno, Mihalj, Blace i Podgradina ${ }^{2}$. Pridjevi su se ispitivali ciljanim upitnikom, a dio je potvrda dobiven iz slobodnoga govora ispitanika ${ }^{3}$. Građa je snimljena diktafonima (Zoom H4 Handy Recorder i Sony ICD-UX513F), preslušana i zabilježena tradicionalnom dijalektološkom hrvatskom transkripcijom.

U prvome dijelu rada opisat će se temeljni podatci o pridjevima, a kako su u dosadašnjoj dijalektološkoj literaturi oskudni radovi koji se dotiču naglasne problematike pridjeva, cilj je rada prikazati trenutačno naglasno stanje pridjeva u slivanjskim govorima, ali i pokušati utvrditi sličnosti i razlike s ostalim štokavskim govorima, posebice onima u dodiru.

$\mathrm{U}$ analizi se naglasnih tipova pridjeva primjenjuje metodologija iz recentnih dijalektoloških morfoloških radova (Kapović 2011, Benić 2013, Gudek 2013), odnosno posebno će se promatrati pridjevi bez sufiksa, tj. korijenski pridjevi, pridjevi sa sufiksima ${ }^{*}$-ьnъ-, ${ }^{*}$-ъkъ, ${ }^{*}$-rь, ${ }^{*}$-lъ, ${ }^{*}$-ęnъ, ${ }^{*}$-enъ-, ${ }^{*}$-avъ, ${ }^{*}$-okъ te ostali pridjevi. Rekonstrukcije i povijesni izvodi pridjeva preuzeti su iz Kapović 2011.

U govorima slivanjskoga područja pridjevi mogu pripadati trima naglasnim paradigmama (n. p. A, n. p. B i n. p. C). U n. p. A naglasak je nepomičan i na osnovi, te se kratkosilazni naglasak ostvaruje u muškome, ženskome i srednjemu rodu (primjerice rädosan - rädosna - rädosno). U n. p. B prije nastavka u m. r. ostvaruje se kratkosilazni ili dugosilazni naglasak, ako je riječ o jednosložnim pridjevima, ili dugouzlazni, ako je riječ o dvosložnima, a u ž. r. i sr. r. kratkouzlazni ili dugouzlazni naglasak (primjerice pün - pùna - pùno, blâg - blága - blágo : dúžan - dúžna - dúžno). U n. p. C događa se promjena naglaska; na polaznim oblicima m. i sr. r. ostvaruju se dugosilazni i kratkosilazni naglasci, a u ž. r. dugouzlazni ili kratkouzlazni (primjerice glûv - glúva - glûvo : stâr - stàra - stâro). Katkad se pojavljuje i tzv. n. p. $C_{1}$ u kojoj se u m. r. umjesto dugosilaznoga ostvaruje dugouzlazni naglasak, u ž. r. dugouzlazni, a u sr. r. dugosilazni, tipični naglasak za n. p. C (primjerice: žédan - žédna - žêdno). Iza pridjeva će se u zagradama bilježiti kratica istraženoga punkta (Slivno Ravno - SR, Mihalj - Mi, Blace - Bl, Podgradina - Po), a kada su pridjevi zabilježeni u svim slivanjskim govorima, kratice se neće navoditi. Kosom se crtom odvajaju primjeri koji se razlikuju fonološkim (razlike u vokalizmu, konsonantizmu ili prozodiji) ili morfološkim sastavom.

\footnotetext{
2 O fonologiji mjesnoga govora Podgradine više u Vukša Nahod 2015b.

3 Riječ je o osobama rođenima i odraslima u istraživanim mjestima, uglavnom starije životne dobi. Ispitanici su bili: Jerka Ključe (r. 1944.), Danka Prović (r. 1949.), Kata Prović (r. 1947.), Ante Mađor (r. 1931.), Ivo Mađor (r. 1936.), Mila Kadijević (r. 1926.), Mila Kadijević (r. 1933.), Joško Bartulović (r. 1921.), Nevenka Vodanović (r. 1939.), Luka Sršen (r. 1931.), Manda Sršen (r. 1937.), Branko Mataga (r. 1929.), Anđelka Popović (r. 1930.), Paulina Bjeliš (r. 1941.), Ivo Ključe (r. 1949.) i Jozo Mušan (r. 1949.). Svima dugujem veliku zahvalnost jer ispitivanje naglasnih paradigama doista iziskuje vremena i strpljenja.
} 


\section{Pridjevi}

U svim je slivanjskim govorima za pridjeve relevantna gramatička kategorija roda (muški, srednji i ženski), broja (jednina i množina), padeža, kategorija 'živo'/'neživo' u jednini m. r. te kategorija 'određenost'/'neodređenost' u N jd. svih triju rodova. Po značenju, tradicionalno se dijele na opisne, posvojne i gradivne ili na opisne i odnosne. Opisni i gradivni mogu biti određeni i neodređeni. Posvojni su pridjevi izvedeni sufiksima -ov, -ev, -in neodređeni, te se sklanjaju po imeničkoj deklinaciji: svề dosèlili iz Pòpova pōla (SR), iz Hütova bläta (SR), u vêlikōn víru je bàcalo bükova lîšća (SR), iskríži kàpulē i mäslinova üḷ (Mi); od stričeva djéla (SR); òna je udáta za Slávkina bräta Nikolu, drïto Jádirina kafíća ìmā böks (Po). Odnosni pridjevi tvoreni sufiksima -sk-ī, -čk-ī, -ń-ī, -jī samo su određeni te se dekliniraju po zamjeničko-pridjevskoj deklinaciji: u nerètvanskīn kńïgan (Po); lòvačkī ìspit (Bl); zâdńī kòvāč (Mi); vàs je vräžjì (SR).

Stupnjevati se mogu samo opisni pridjevi. U pozitivu je ovjerena razlika po određenosti, dok komparativ i superlativ iskazuju samo određenost. U funkciji predikata pridjev je najčešće neodređenoga oblika: pòd krāj büdē sûv (Mi), jâ san vìtak (Bl), čầvã je bïjā về̆ nëšto drügō, ôn je bìjā kvàdrātan, käko bi rêkā, ceêttverokûtan, a brôkva je òbla (Po), ali i određenoga: plinor ${ }^{4}$ je vèlikī (Mi), kà je ôn bìo mälešni (SR), rázlika ìzmešu brökvēi čâvla; čầvā je bìja kồvānī (Po). U funkciji atributa dolazi u određenome obliku: tô je bîlo prâvō, dòmācé bräšno (SR), môj mâlì ùnuk (Mi), svề ôvī nồvī plèsovi dòlazē od cr̂onācā (Bl), ù nās je nèstā òtočicư nă ūšcu, lîpi, mâlī òtočič (Po). Zabilježeno je i da pridjev nerijetko dolazi iza imenice: mälo smökāvā sûvijēn (SR), tâ ti je stála rôba tànkā (Mi), u kùžīni stârōn (Bl), bìjā je mòstič ổbal, lípa je ko Góspa Blážena (Po), slîka Góspina (Po), u vrïči zàvēzanon (Po), pa donèse önü čìkaru ${ }^{5}$ mâlū (Po). U dvorječnim je toponima pridjev uvijek u određenome obliku: Slîvno Râvnō (SR), u Kràpinnskijēn Tòplican (Mi), Nôvā Sëla (Bl), ù Bīlōn Víru (Po).

Katkad se neki pridjevi pojavljuju u imeničkoj funkciji: u Dùbokōn L, Pàlinićevo, mlâdā, žènskā, slätko, cr̂onōga (SR, Bl, Po)/cr̂̀nōga (Po) G jd.

\subsection{Osnova i nastavak}

Pridjev tvore osnova (korijen i sufiks) te nastavak, a osnova se dobije izostavljanjem nastavka bilo kojega oblika.

Između dvaju posljednjih konsonanata osnove neodređenoga lika u $\mathrm{N}$ i A jd. m. r. kod nekih je pridjeva ovjereno nepostojano - $a$ - u svim slivanjskim govorima: bìstar : bistra, bôlesan : bölesna, čùdan (SR, $\mathrm{Mi}, \mathrm{Bl}) / c$ cù̀dan (Po) : čùdna (SR, Mi, $\mathrm{Bl})$ /čùdna (Po), döbar : dòbra, dúžan : dúžna, glädak : glàtka, kivan : kívna, krâtak : krátka, ládan : ládna, míran : mírna, mökar : mòkra, múdar : múdra, nìzak : nìska, öštar : òštra, pämetan : pämetna, pïtak : pitka, slädak : slàtka, srêttan: srètna, šúpal (SR, Mi, Bl)/šúpaj (Po) : šúpla (SR, Mi, $\mathrm{Bl}$ )/šúpja (Po), túžan : túžna, vrídan : vrídna (Bl, Po), žälosan : žălosna, žédan : žédna.

\footnotetext{
4 Plinor - gnjurac.

5 Čikara - šalica za kavu.
} 


\subsection{Neodređeni vid}

Razlika između neodređenoga i određenoga vida u $\mathrm{N} \mathrm{jd.} \mathrm{svih} \mathrm{triju} \mathrm{rodova} \mathrm{pridjeva}$ očuvana je u svim slivanjskim govorima. Također, u mnogim je primjerima u potpunosti očuvana sklonidba neodređenih pridjeva, iako u kosim padežima postupno dolazi do ujednačavanja ${ }^{6}$. Neodređeni se pridjevi dekliniraju po imeničkoj deklinaciji.

\begin{tabular}{|c|c|c|c|c|c|c|}
\hline & m.r.jd. & sr. r.jd. & ž. r. jd. & m. r. mn. & sr. r. mn. & ž. r. mn. \\
\hline $\mathrm{N}$ & $-\varnothing$ & $-o /-e$ & $-a$ & $-i$ & $-a$ & $-e$ \\
\hline G & $-a$ & $-a$ & $-\bar{e}$ & $-\bar{\imath}$ & $-\bar{\imath}$ & $-\bar{\imath}$ \\
\hline $\mathrm{D}$ & $-u$ & $-u$ & $-\bar{o} n$ & $-i n$ & $-i n$ & $-i n$ \\
\hline $\mathrm{A}$ & $=N / G^{7}$ & $=N$ & $-u$ & $-e$ & $=N$ & $=N$ \\
\hline $\mathrm{L}$ & $-u$ & $-u$ & $-\bar{o} n$ & $-\bar{i} n$ & $-\bar{i} n$ & $-\bar{i} n$ \\
\hline $\mathrm{I}$ & $-i \bar{n}$ & $-i \bar{n}$ & $-\bar{o} n$ & -īn & $-\bar{i} n$ & $-\bar{i} n$ \\
\hline
\end{tabular}

m. r.: N jd. bölesan, gládan, glûv, gô 'gol', ìtar 'hitar', kívan, krâtak, ládan, mëk, mlâd, öhol, öštar, pämetan, pïtak, plïtak, sït, sïtan, släb, skûp, srëtan, škrr̀t, zlöban, žălosan, dèbevo (SR, Mi, Bl); bîl, blîd, lîp, sîd, smiśsan (Bl, Po); čùpav, dèbel, drêt 'uspravan', dùgačak, ùpotan 'znojan', stř̀pjiv, škïjav, špôrak 'prljav' (Po), G jd. ćôrava, dùga, krâtka, pišjiva (Po), súva, D jd. dòbru, sìtu, A jd. zdrâva, žâlosna, žédna, L jd. mlâdu, N mn. brdòviti, dòbri, jâdni

sr. r.: N jd. bölesno, bôso, brezòbrazno, čisto, drèto 'uspravno', dügo, glûvo, gòlo, kívno, kr̂̀vavo, lâdno, môkro, plávo, plitko, pûsto, sìto, spôro, sprềtno, tồplo, zdrầvo, žâlosno, žîvo; bílo, blîdo, lîpo, rîtko, smišno, vrídno (Bl, Po); cuùpavo, mütavo, škïjavo, špôrko, šúpje, träjavo, žestòko (Po), G jd. téška, vêdra, I jd. bösīn, sprêtīn, $\mathrm{N} \mathrm{mn}$. čista, D mn. pûstin, slánin, tôplin ž. r.: N jd. bälava, bölesna, bòsa, crvèna, dòbra, dubòka, gòla, gr̂̀bava, gústa, kìsela, ládna, mànita, mòkra, múdra, mütava, pämetna, pittka, pláva, poštèna, rumèna, rädosna, sprètna, stàra, šarèna, tòpla, túžna, ùska, visòka; bíla, rítka, sída, slípa, smíšna, vrídna (Bl, $\mathrm{Po})$; kr̂̀vava, špórka (Po), G jd. bòsēe, gòlē, zdrầvē, D jd. dòbrōn, jâdnōn, slánōn, A jd. múdru (Mi), túźu (SR), rítku, slípu, vèliku (Bl, Po)

U N/A jd. sr. r. nastavak -o potvrđen je u osnovama s nepalatalnim završetkom: mëko, öštro, pûsto, sìrovo, sìto, žâlosno, vêselo ( $\mathrm{SR}, \mathrm{Mi}, \mathrm{Bl}, \mathrm{Po}$ ), a nastavak -e nalazimo u

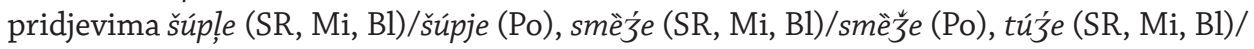
túže (Po) jer im osnova završava na palatal. Iznimka je pridjev lǐš 'gladak': lǐšo.

U svim je mjesnim govorima slivanjskoga područja u D/L jd. ž. r. zabilježen nastavak -ōn: dòbrōn, jädnōn, slánōn.

${ }^{6}$ U susjednome zapadnom štokavskom dijalektu čuvanje razlike između određenih i neodređenih pridjeva $\mathrm{u}$ nominativu te mjestimično čuvanje te razlike u kosim padežima u jednini vodi do potpunoga ukidanja razlike između određenih i neodređenih pridjeva u množini kod većine ispitanika (v. Kurtović Budja 2009: 108-110).

7 Ako imenica na koju se pridjev odnosi znači što živo, A. jd. jednak je G jd., ako pak znači što neživo, jednak je $\mathrm{N} \mathrm{jd}$. 
Takvo je stanje u govoru Slivna Ravnoga i Kleka zabilježio i Halilović (1996: 176), ali uz postojanje dvostrukoga ostvaraja -om/-on. Istraživši područje od Neretve do Rijeke dubrovačke, ustvrdio je da nastavak -oj postoji samo u govorima istočnohercegovačkoga tipa, i u govorima Zažablja, što govori o unutarnjoj diferencijaciji slivanjsko-zažapskoga govornog tipa, dok nastavak -om dominira u većini govora dubrovačkoga i pelješkoga tipa. Istaknuo je da je pojava nastavka -om/-on zabilježena i u dolinama Neretve (Jablanica), Rame i Drežnice, na području Makarskoga primorja te u susjednoj čakavštini Halilović (1996: 175). Vidović (2014: 40) pak tvrdi da se u Vidonjama ${ }^{8}$ dativ i lokativ ženskoga roda zamjeničko-pridjevske sklonidbe ipak može tvoriti nastavkom -ōm/-ōn, ali rjeđe nego u Slivnu.

U zapadnome štokavskom dijalektu također je zabilježen nastavak -ōn te se u D jd./L jd. ž. r. pojavljuje dosljedno, kako je terenskim istraživanjem govora Makarskoga primorja potvrdila Kurtović Budja (2009: 110) te sungerskoga govora u Gorskome kotaru Crnić Novosel (2015: 204-205) ili supostoji s nastavkom -ōj $j^{9}$, kako je u govoru Bitelića u Sinjskoj krajini zabilježila Ćurković (2014: 176). U Vrgorskoj je krajini ovjeren samo nastavak -ōn (Kapović, usmeno).

U slivanjskim se govorima rodbinski odnosi uglavnom iskazuju posvojnim pridjevima: brâtov, bäbin, ćâcín (SR, Mi, Bl)/čầčin (Po), žêdov (SR, Mi)/dìdov (Bl, Po), sèstrin, svêkrov, no katkad se ostvaruje sintagma od + imenica: òd brata sîn, od sèstrē cêr, od sèstrē mi mûž, od sîna mâlĭ, od mûža brät. Ista je pojava potvrđena kod gradivnih pridjeva: dr̀venī stôl : od dr̂̀va stôl, sùknene gäće : od súkna gâce, vùnene mödrine : òd vùne mödrine.

\subsection{Određeni vid}

Određeni se pridjevi dekliniraju po zamjeničko-pridjevskoj deklinaciji.

\begin{tabular}{|c|c|c|c|c|c|c|}
\hline & m.r.jd. & sr. r. jd. & ž. r. jd. & m. r. mn. & sr. r. mn. & ž. r. mn. \\
\hline $\mathrm{N}$ & $-\bar{\imath}$ & $-\bar{o} /-\bar{e}$ & $-\bar{a}$ & $-\bar{\imath}$ & $-\bar{a}$ & $-\bar{e}$ \\
\hline G & -ōga/-ēga & -ōga/-ēga & $-\bar{e}$ & $-\bar{l} /-i j \bar{e}(n)$ & $-\bar{i} /-i j \bar{e}(n)$ & $-\bar{l} /-i j \bar{e}(n)$ \\
\hline $\mathrm{D}$ & $-\bar{n} n$ & -ōn/-ēn & $-\bar{n} n$ & $-i \bar{n} /-i j \bar{e}(n)$ & $-i \bar{n} /-i j \bar{e}(n)$ & $-i \bar{n} /-i j \bar{e}(n)$ \\
\hline $\mathrm{A}$ & $=N / G$ & $=N$ & $-\bar{u}$ & $-\bar{e}$ & $=N$ & $=N$ \\
\hline $\mathrm{V}$ & $=N$ & $=N$ & $=N$ & $=N$ & $=N$ & $=N$ \\
\hline $\mathrm{L}$ & -ōn/(-ōme) & $-\bar{o} n /-\bar{e} n$ & $-\overline{o n}$ & $-\bar{i} n /-i j \bar{e}(n)$ & $-\bar{i} n /-i j \bar{e}(n)$ & $-i \bar{n} /-i j \bar{e}(n)$ \\
\hline $\mathrm{I}$ & $-\bar{i} n /-i j \bar{e}(n)$ & $-i \bar{n} /-i j \bar{e}(n)$ & $-\bar{n} n$ & $-i \bar{n} /-i j \bar{e}(n)$ & $-i \bar{n} /-i j \bar{e}(n)$ & $-i \bar{n} /-i j \bar{e}(n)$ \\
\hline
\end{tabular}

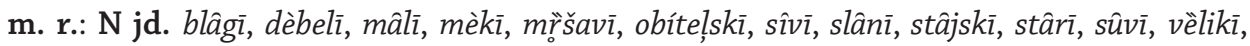

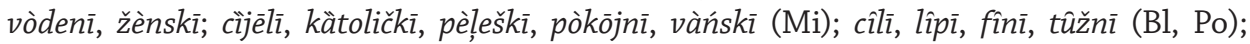

8 Govor je Vidonja novoštokavski ijekavski te pripada slivanjsko-zažapskomu govornom tipu.

9 Nastavak -ōn u govoru Bitelića uglavnom je potvrđen kod starije generacije. 
špôrkī, vrûcì (Po), G jd. mâlōga, prâvōgā, vêlikōga, zâdńēgā, A jd. cîlì (Bl, Po), L jd. bồlesnōn, küćnōme, mûdrōn, stäračkōn, I jd. sûvīn, slânīn, žălosnīn, N mn. dòmāćī, G mn. pòl̦skijē, mòrskijēen, L mn. rûbnīn (Bl, Po)/rûbnijēen) (SR, Mi), sêoskīn (Bl, $\mathrm{Po}$ )

sr. r.: $\mathrm{N}$ jd. čìstō, dòmācée, jädnō, mâlō, mèkō, plitkō, prâvō, släbō, slánō, sûvō, tồplō, vềlikō,

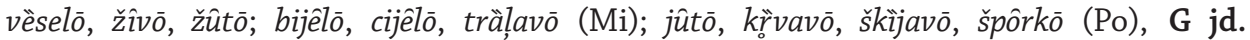

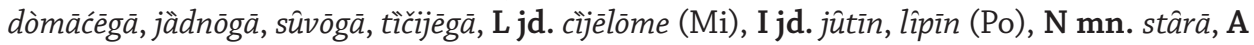
mn. vềikā, G mn. prâvī, mèkī, nôvì (SR), L mn. slânijēen) (SR, Mi), zabačènijīn (Bl)

ž. r.: N jd. bälavā, bölesnā, čìstā, frèškā, mütavā, nồvā, pämetnā, pitkā, pòkōjnā, pöznātā, rumènā, râdosnā, stârā, vềikā, vî̀novā, žîvā; bijêlā (Mi), cîlā, bîlā (Po), G jd. pitkē, plávē, tòplē, D jd. dèsnōn, mlâdōn, A jd. cîlū (Bl, Po), mâlū, vềlikū, pûtnū, L jd. ù mālōn, râdnōn, sèlačkōn, stârōn, vëlikōn, I jd. kṛ̛̆šnōn, òblōn, vëlikōn, $\mathrm{N}$ mn. dì̀venē, mâlē, mlâdē, sèzōnskē, stârē, vềlikē, G mn. vềíjē, stârìjē (Mi), vèlikì, pầmetnī (Bl, Po), A mn. òtrōvnē, $\mathrm{D}$ mn. dèbelijēn, tửzijēn, sûvijēn, vèlikijēn (SR, Mi), čìstīn (Bl), I mn. sûvīn (Po)

U osnova s nepalatalnim završetkom u N/A jd. sr. r. ovjeren je nastavak -o: bösō, čistō, dügō, glûvō, plitkō, bílō (Bl, Po), a u osnova s palatalnim završetkom, komparativu i u superlativu sr. r. potvrđen je nastavak -e: smëżé (SR, Mi, BL)/smë̌̌e (Po), dräžēe, düžé,

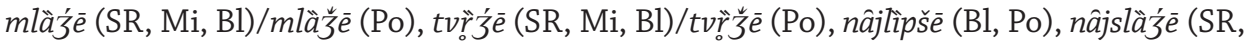
$\mathrm{Mi}, \mathrm{Bl}) / n a ̂ j s l a ̈ ̧ ̌ e ~(\mathrm{Po})$.

U L jd. m. r. u govoru Mihalja rijetko se pojavljuje i nastavak -ōme, koji nije zabilježen u drugim istraživanim govorima.

U govorima Slivna Ravnoga i Mihalja ovjereni su nastavci starih tvrdih osnova u I jd. m. i sr. r. -ijēe(n), G mn. -ijē i D/L/I mn. -ijēen) m., sr. i ž. r., iako se mogu realizirati i nastavci starih mekih osnova, koji su prevladali u govorima Blaca i Podgradine: I jd. -in, G mn. -ì, a D/L/I mn. -ìn. Halilović ne donosi konkretne podatke o nastavcima tih padeža u slivanjskim govorima, iako ih potvrđuje u zažapskim govorima te ostalim govorima od rijeke Neretve do Rijeke dubrovačke (Halilović 1996: 188).

\subsection{Komparativ}

U slivanjskim se govorima komparativ tvori od osnove pozitiva:

- sufiksom -š- (samo u navedenim primjerima): läkšš, lềpšì (SR, Mi)/lìpšž (Bl, Po), mềšĩ

- sufiksom -ji- (u jednosložnim pridjevima s kratkim ili dugim naglaskom na osnovi ili višesložnim pridjevima): bìstrijī, bogàtijī, glàdnijī, krùpnijī, làdnijī, òštrijī, pamètnijī, rùžnijī, sitnijīi, slàbijī, slànijī, sprètnijī, sritnijī (Bl, Po), stàrijī, ukùsnijī, vrùcijīi (SR, Mi, $\mathrm{Bl})$ /vrùcỉij $(\mathrm{Po})$, zabačènijīi $(\mathrm{Po})$, zelènijī, zdàvijī, žalòsnijī

- sufiksom -j- (od jednosložnih pridjeva s kratkim ili dugim naglaskom na osnovi te od osnova sa sufiksima -ok- i -ak- koji se u komparativu odbacuju), pri čemu dolazi do morfonoloških alternacija, tj. promjene konsonanata na dočetku osnove u svim

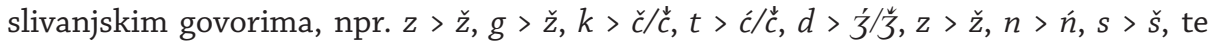
umetanja epentetskoga -l- između dočetnoga konsonanta osnove i sufiksa -j- u govorima Slivna Ravnoga, Mihalja i Blaca: 


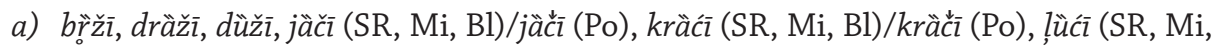

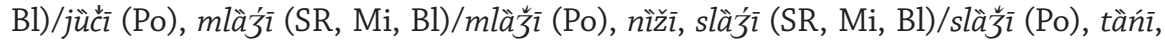

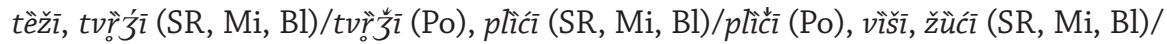
žüčci (Po), žěšćì (SR, Mi, Bl)/žêščì (Po)

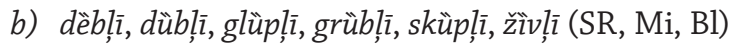

c) dèbjī, dübjī, glüpjī, grübjī, sküpjī, žìvjī (Po).

Supletivni oblici komparativa potvrđeni su u svim govorima: döbar - bōḹi (SR, Mi,

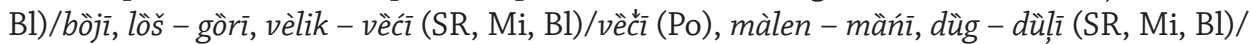
düjī (Po) (uz düžì).

U komparativu su potvrđeni sljedeći nastavci:

-i (m. r. jd.) // -i (m. r. mn.)

-e (sr. r. jd.) // -a (sr. r. mn.)

-a (ž. r. jd.) // -e (ž. r. mn.).

\subsection{Superlativ}

Superlativ se u slivanjskim govorima tvori tako da se komparativu doda prefiks

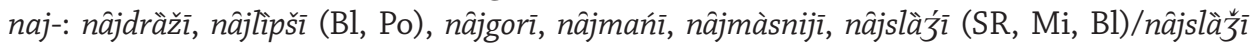

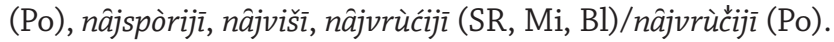

Zabilježeno je da se nekim pridjevima koji zapravo nisu komparativi, ali mogu imati komparativno značenje, također dodaje prefiks naj-: nâjdońī, nâjgorńī, näjprvō, nâjzàdńī.

Katkad je zabilježeno odvajanje prefiksa naj- od komparativa, i to samo u govoru Mihalja: nâj smo mi sličnijī sa Slîvnon, nâj su vǐšì Máte i Józo.

\section{Naglasne paradigme pridjeva}

\subsection{Korijenski pridjevi (bez sufiksa)}

Naglasna paradigma $B$

\begin{tabular}{|l|c|c|c|}
\hline & m. $\mathbf{r}$. & ž. $\mathbf{r}$. & sr. . \\
\hline Slivno Ravno & gô & gòla & gòlo \\
\hline Mihalj & čìs & čìsta & čìsto \\
\hline Blace & plâv & pláva & plávo \\
\hline Podgradina & bîl & bíla & bílo \\
\hline
\end{tabular}

SR n. p. B: bjêl, blêed, cr̂on, čìs 'čist' (i n. p. C), gô, läk, mëk (i n. p. C), mr̆̀k (i n. p. C), nôv (i n. p. C), plâv, pün, rì̉, sîv, släb (i n. p. C), sjêd (i n. p. C), vrêl, vrûć, zdrêl, žût

Mi n. p. B: bìjēl, blâg, br̆̀z (i n. p. C), cr̂̀n, č̀ll (i n. p. C), čìs 'čist', gô, jâk, làk, ḷ̂ut, nồv, plâv, pün, sîv (i n. p. C), sijêd, slân (i n. p. C), smëź, tvr̆̀d, vrël 
Bl n. p. B: bîl, blîd, bôs, br̆̀rz, cr̂on, čìs 'čist', gô, jâk (i n. p. C), läk, nồv, vrël, plâv, pün, slân, sîd, sîv, žût

Po n. p. B: bîl, blîd, bôs, brìz, cr̂̀n, cù̀s 'čist', gô, jâk, läk, lîp, nồ, plâv, sîd, sîv, slân, vrêl, zdr̂̀av, žût

Naglasna paradigma $C$

\begin{tabular}{|l|c|c|c|}
\hline & m. $\mathbf{r}$. & ž. $\mathbf{r}$. & sr. . \\
\hline Slivno Ravno & bôs & bòsa & bòso \\
\hline Mihalj & drèt & drèta & drèto \\
\hline Blace & gûst & gústa & gûsto \\
\hline Podgradina & slîp & slípa & slîpo \\
\hline
\end{tabular}

SR n. p. C: blâg, bôs, br̆̀z, cjêl, č̀s (i n. p. B), drâg, drêt 'uspravan', dùg, glûv, glûp, gńîl, grûb, gûst, jâk, löš, lûd, kôs, krîv, krût, mëk (i n. p. B), mlâd, mř̀k (i n. p. B), nồv (i n. p. B), ńêm, prầv 'uspravan', pròst, pùn, sìt, sâm, skûp, slân, slêep, sjêd (i n. p. B), släb (i n. p. B), smèź', spôr, stàr, strôg, sûv, svêt, škr̂̀t, tîh, trôm, vjëš 'vješt', zdrầ, žîv

Mi n. p. C: bôs, br̆̀z (i n. p. B), čìl (i n. p. B), düg, glûv, gńîl, gûst, jâk, lìjēn, lìš 'gladak', lôš, mëk, mlâd, pḷàn 'pijan', prầv 'uspravan', sìt, sîv (i n. p. B), släb, slân (i n. p. C), stâr, stròg, skûp, sûv, škrìt, tïh, tûp, zdrèo, žîv

Bl n. p. C: drâg, dùg, glûp, glûv, gńîl, gûst, jâk (i n. p. B), löš, lûd, mlâd, pràv, sìt, släb, skûp, spôr, stär, stròg, sûv, škř̀t, zdrầv

Po n. p. C: drèt 'uspravan', dùg, glûp, glûv, gńîl, gûst, jût, löš, lûd, mlâd, prầ, sìt, skûp, släb, slîp, spör, stär, strög, škř̀t, sûv

U slivanjskim govorima n. p. A korijenskih pridjeva nije potvrđena, te uočavamo tendenciju prelaska starih pridjeva n. p. a u n. p. B: čìst, lāk, pün, vrêl, zdrèl (u Mi n. p. C) ili u n. p. C: löš, pràv, prôst, sìt, spôr, strôg, stär, škr̂̀t, tîh, trôm, vjēš 'vješt', zdrâv, dok kod nekih bilježimo kolebanja između n. p. B i n. p. C: čìs, mêk, släb, mř̀k i sl. Ta promjena nije neobična za organske štokavske govore, posebice za one istočnohercegovačkoga i novoštokavskoga ikavskog dijalekta. Vidović (2007: 209) u novoštokavskim ijekavskim govorima Dobranja i Vidonja u Neretvanskoj krajini bilježi da pridjevi: zrêo, düg, löš, strôg idu po n. p. C, a pridjev pün po n. p. B. Kapović (2011: 108-109) navodi da u zapadnoštokavskim dalmatinskim govorima osim prelaska korijenskih pridjeva n. p. A u n. p. B, gotovo svi pridjevi prelaze u n. p. C, izuzev pridjeva pùn koji od Imotskoga preko Vrgorca do Neretve ide u n. p. B. Za mjesni govor Prapatnica u Vrgorskoj krajini donosi da u n. p. C idu pridjevi: düg, č̀st, kr̆t,

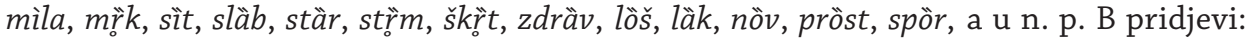
pün, vrìja 'vrel' i zrìja 'zrel'. Kurtović Budja (2009: 132) za govore Makarskoga primorja također donosi da pridjev pün ima oblike n. p. B, dok se pridjevi čist, düg, mëk, mr̈k, nòv, prầ, škr̂̀t, släb, stâr, zdrầv nalaze u n. p. C. Šimundić (1971: 126-127) za govore Imotske krajine i Bekije bilježi da pridjevi č̀st, dug, mek, mrk, nov, prav, slab, star, škrt, 
zdrav ${ }^{10}$ pripadaju n. p. C, pridjev pün n. p. B, dok kod pridjeva läk i tìj bilježi n. p. B i n. p. C. Ćurković (2014: 179-180) za govor Bitelića donosi da pridjevi düg, nôv, pün, släb, stär, zdrâv pripadaju n. p. B, a samo pridjev cìst n. p. C. Prema dostupnim podatcima zasad možemo zaključiti da je u spomenutih pridjeva prelazak n. p. $a>$ n. p. B najizrazitiji u govorima Sinjske krajine. Za govore Neretvanske, Vrgorske i Makarske krajine karakterističnija je promjena n. p. $a>$ n. p. $C$.

Pridjevi nôv u slivanjskim govorima nije prešao u n. p. A, iako je to potvrđeno u mnogim štokavskim govorima zbog jednakoga odraza staroga akuta (n. p. a) i kratkoga neoakuta (n. p. b) u kratkosilaznome naglasku, jer ona nije očuvana ni kod pridjeva koji su iskonski pripadali n. p. a. Tako je i pridjev gô, u kojemu je dugosilazni naglasak posljedica vokalizacije dočetnoga -l i stezanja ostao u n. p. B.

Ostali korijenski pridjevi u n. p. B izrazito su rijetki te su to uglavnom oni koji označuju boje: bjêl (SR)/bìjēl (Mi)/bîl (Po), sîv (u Mi i n. p. C), žût, cṛ̂n (SR, Mi, Bl)/cr̂̀n (Po), blêd (SR)/blìd (Bl, Po), plâv, sjêd (SR)/sijêd (Mi)/sîd (Bl, Po). Pridjevi bjêl/bïjēl/bîl, žût i cr̂nn/cr̂̀n pripadali su n. p. $b$ pa su se prema njima ujednačili i ostali: sîv iz n. p. $a$ te plâv i sjêd sijêd/sîd iz n. p. c, koji je sačuvao oblike i n. p. C. I u ostalim štokavskim govorima slična je situacija. Vidović (2013: 166) navodi da se pridjevi plâv, žût, cr̂on ubrajaju u n. p. B u govorima Zažablja i Popova. U n. p. B u mjesnome govoru Prapatnica u Vrgorskoj krajini (Kapović 2011: 341) nalaze se pridjevi: cr̂nn, bìja 'bijeli', rîđ, sîv, žût, blîd, dok za govore Imotskoga i Bekije Šimundić (1971: 130-131) bilježi da pridjevi blîd, crn, plâv, rîđ, sîd, žût mogu ići i po n. p. B i po n. p. C. Kurtović Budja (2009: 132) u govorima Makarskoga primorja zabilježila je samo pridjev blîd, koji je dijelom n. p. B, dok Ćurković (2014: 181) u govoru Bitelića nalazi samo n. p. B: bîl, blîd, cr̂̀n, plân, sî̀, žût.

U slivanjskim je govorima potvrđen velik broj pridjeva koji idu po n. p. C, koja je odraz iskonske n. p. c, te oni čine najbrojniju skupinu. Vidljivo je da ne dolazi do prelaska pridjeva koji su pripadali n. p. c u n. p. B, niti kolebanja među njima, te bilježimo glûv - glúva - glûvo, gńîl - gńíla - gńîlo, mlâd - mláda - mlâdo, slân - slána - slâno. Po toj se značajci istraživani govori mogu povezati sa zapadnoštokavskim govorima u kojima je čuvanje n. p. C uobičajeno.

Sinkronijsku n. p. C bilježi i Vidović (2007: 209) u govorima Dobranja i Vidonja u Neretvanskoj krajini: mlâk, glûp, tûp, žîv, gńîl, čvr̂ss, slân, dok pridjevi tûd i svêt prelaze u n. p. B. Kurtović Budja (2009: 132) u govorima Makarskoga primorja bilježi izrazito čuvanje n. p. C: blâg, čvr̂sst, jâk, drâg, glûv, grub, gûst, lûd, jût, mlâd, sâm, slân. Kapović (2011: 356) ističe da se u govoru Prapatnica u Vrgorskoj krajini n. p. C također čuva, navodeći među ostalim primjere: sûv, br̂̀z, čvr̂ss, drâg, glûv, gûst, krîv, lîn, lîp, l̦̂̀t, lûd, pûst, skûp, dok pridjevi blâg, blîd, gńîl, jâk, mlâk, sâm idu po n. p. B, a slično je i u Imotskoj krajini i Bekiji (Šimundić 1971: 130), gdje su pridjevi lîp, čvrs, grub, slan, živ dijelom n. p. C, a pridjevi blag, gnjil, jak, mlad n. p. B. Ćurković $(2014: 182,184)$ pak u govoru Bitelića bilježi da pridjevi lîp, lûd, l̦ût, gûst, mlâd, sâm, slân idu po n. p. B, dok ne nalazi primjere za n. p. C, što ističe kao osobitost

10 Svi primjeri koji se u radu donose bez naglaska tako su zabilježeni u korištenoj literaturi. 
govora okolice Sinja. Razvidno je da je sinkronijska n. p. C najbolje očuvana u slivanjsko-zažapskim govorima i susjednim govorima Makarskoga primorja.

U govoru Slivna Ravnoga i Mihalja u n. p. C sačuvao se i jedini jednosložni pridjev s kratkim slogom na osnovi koji je izvorno pripadao n. p. c: bôs - bòsa - bòso, dok je u govorima Blaca i Podgradine prešao u n. p. B: bôs - bòsa - bòso, ali je sačuvao svoj osnovni oblik, odnosno dužinu u muškome rodu. Prelazak u n. p B. zabilježio je i Vidović (2007: 209) u govorima Vidonja i Dobranja. U susjednim govorima Makarskoga primorja Kurtović Budja (2009: 132) bilježi čuvanje n. p. C, kako je u govorima Imotske krajine i Bekije zabilježio Šimundić (1971: 131), te u govorima Vrgorske krajine Kapović (2011: 109). Ćurković (2014: 182) pak navodi kako je u govoru Bitelića došlo do prelaska u n. p. B.

\subsection{Pridjevi na -an (*-bnъ-)}

Naglasna paradigma A

\begin{tabular}{|c|c|c|c|}
\hline n. p. A & m.r. & ž. r. & sr. r. \\
\hline Slivno Ravno & ràdosan & ràdosna & rädosno \\
\hline Mihalj & žàlosan & žàlosna & žàlosno \\
\hline Blace & bölesan & bölesna & bölesno \\
\hline Podgradina & pàmetan & pàmetna & pàmetno \\
\hline
\end{tabular}

SR n. p. A: bölesan, jâdan, làgan, pâmetan, rädosan, sìtan, skrôman, slīčan, slöbodan, sprètan (i n. p. C), žàlosan, vjêčan

Mi n. p. A: bòlesan, jàdan, pàkosan, pàmetan, prầvedan, ràdosan, sìtan, slīčan, slöbodan, sprètan, žàlosan

Bl n. p. A: bòlesan, jàdan, màlakan 'malen', pàmetan, ràdosan, prìjāzan, sìtan, slöbodan, strášan, žàlosan

Po n. p. A: bòlesan, jâdan, pämetan, pràvedan, râdosan, sìtan, slöbodan, strášan, üpotan 'znojan', vïčan, žälosan

Naglasna paradigma $B$

\begin{tabular}{|l|c|c|c|}
\hline \multicolumn{1}{|c|}{ n. p. B } & m. $\mathbf{r}$. & ž. $\mathbf{r}$. & sr. . \\
\hline Slivno Ravno & túžan & túžna & túžno \\
\hline Mihalj & kívan & kívna & kívno \\
\hline Blace & vrídan & vrídna & vrídno \\
\hline Podgradina & smíšan & smíšna & smíšno \\
\hline
\end{tabular}

SR n. p. B: búdan, bjédan, bújan, dúžan, kivan, másan, míran, mútan, prázan, rávan, rúžan,

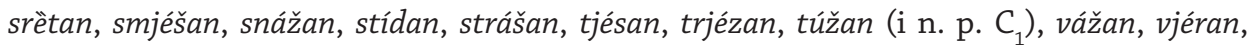
vrjédan (i n. p. $C_{1}$ ), závidan, zlátan 
Mi n. p. B: búdan, kívan, dúžan, gládan (i n. p. C), másan, míran, prázan, rávan, spòsoban, sjeròmašan/śeròmašan ${ }^{11}$, strášan, smijéšan, vjéran, závidan, žélan

Bl n. p. B: búdan, dúžan, kívan, gládan, másan, míran, prázan, smíšan, stídan, tísan, túžan, vrídan, závidan, žédan, žélan

Po n. p. B: búdan, dúžan, gládan (i n. p. C), kívan, másan, míran, mútan, prázan, rúžan, smíšan, stídan, tísan, túžan, vrídan, závidan, žéjan

Naglasna paradigma $C$

\begin{tabular}{|l|c|c|c|}
\hline \multicolumn{1}{|c|}{ n. p. $\mathbf{C}$} & m. $\boldsymbol{r}$. & ž. $\mathbf{r}$. & sr. $\mathbf{r}$. \\
\hline Slivno Ravno & grèšan & grèšna & grèšno \\
\hline Mihalj & mòćan & mòćna & mòćno \\
\hline Blace & čùdan & čùdna & čùdno \\
\hline Podgradina & glâdan & gládna & glâdno \\
\hline
\end{tabular}

SR n. p. C: bìtan, čàsan, čùdan, gầdan, glàsan, grèšan, kṛ̌̌an, küžan, mòćan, plôdan, sprètan, srètan (i n. p. B), svjèsan, zlöban

Mi n. p. C: bìtan, čàsan, čùdan, jâdan, gàdan, glâdan (i n. p. B), grêšan, kř̀šan, mòćan, plödan, sprètan, srètan, zlöban

Bl n. p. C: bìtan, čàsan, čùdan, kǐšan, gàdan, môćan, sprêtan, srètan, zlöban

Po n. p. C: bìtan, čàsan, čùdan, gàdan, glâdan (i n. p. B), křš̌an, möčan, sprètan, srètan, zlöban

Naglasna paradigma $C_{1}$

\begin{tabular}{|l|c|c|c|}
\hline \multicolumn{1}{|c|}{ n. p. C $_{1}$} & m. $\mathbf{r}$. & ž. $\mathbf{r}$. & sr. $\mathbf{r}$. \\
\hline Slivno Ravno & túžan & túžna & tûžno \\
\hline Mihalj & znójan & znójna & znôjno \\
\hline Blace & gládan & gládna & glâdno \\
\hline Podgradina & ládan & ládna & lâdno \\
\hline
\end{tabular}

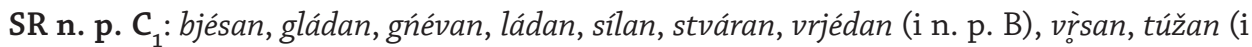
n. p. B), znójan, žédan, žél̦an

Mi n. p. C $\mathbf{C}_{1}$ krúpan, ládan, mútan, rúžan, stídan, túžan, znójan, žédan

Bl n. p. C : ládan, mútan, rúžan

Po n. p. $\mathrm{C}_{1}$ : ládan

Kod pridjeva koji završavaju na -an u slivanjskim su govorima ovjerene sve tri naglasne paradigme. Primjećujemo da ne dolazi do ujednačavanja kratkih pridjeva n. p. c (primjerice möćan, čàsan 'častan') s pridjevima n. p. A, odnosno ostaje möćan - mòćna-

11 Oblik sjeròmašan potvrđen je kod katoličkoga stanovništva, a oblik śeròmašan kod praoslavnoga. 


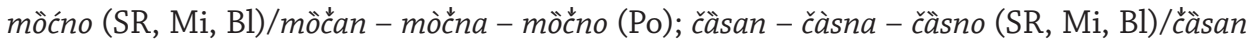
- ćàsna - čâsno (Po). I izvorno dugi pridjevi n. p. c, koji su se naknadno pokratili ${ }^{12}$, uglavnom ostaju u n. p. C: svjêsan - svjèsna - svjêsno; bïtan - bitna - bïtno, no pridjev vjëčan - vjëčna - vjëčno (SR)/vï̌̆an - vï̌can - vï̌́no ipak usustavljuje " naglasak te postaje dijelom n. p. A.

Kod pridjeva kojima osnova završava na sonant (primjerice žẹlıan, vjëran, sïlan), u ž. i sr. r. dolazi do duljenja, što utječe na oblik pridjeva u muškome rodu te dolazi do prelaska u druge paradigme: n. p. B: vjéran - vjérna - vjérno (SR, Mi), žélan - žélna -

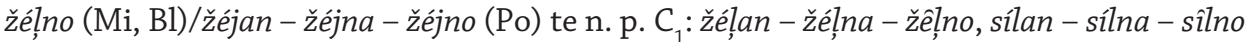
(SR).

Neki su pridjevi iz n. p. a prešli u n. p. C: čùdan - čùdna - čùdno (SR, Mi, Bl)/čùudan

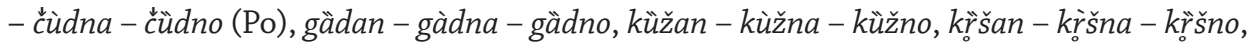
dok su pridjevi jâdan i sìtan ostali u n. p. A. Pridjev srêtan u govoru Slivna Ravnoga pak može ići po n. p. B srëtan - srètna - srètno i n. p. C srëtan - srètna - srêtno, dok je u govorima Mihalja, Blaca i Podgradine dijelom n. p. C. Vidović (2014: 33) u zažapskim govorima također bilježi sekundarno proširenje n. p. C u pridjevima srêtan i zgôdan. Kapović (2011: 379) donosi da su u govoru Prapatnica pridjevi iz n. p. A prešli u n. p. C: sìtan, čùdan, gầdan, jädan, křšsan, küžan, skötan, srïtan, vǐčan. Šimundić (1971: 127) u govorima Imotske krajine i Bekije bilježi kolebanje između n. p. A i n. p. C: čüdan i jädan ili prelazak u n. p. C: sìtan, müčan, gädan. Curković $(2014: 179,183)$ u govoru Bitelića bilježi ili čuvanje n. p. A: jädan, gàdan, müčan ili prelazak u n. p. C: sïtan. Kurtović Budja (2009: 133) u govorima Makarskoga primorja za n. p. A donosi samo pridjev jädan, a za n. p. C pridjev müčan.

U slivanjskim je govorima došlo do ujednačavanja višesložnih pridjeva izvorno $\mathrm{n}$. p. a: pämetan, rädosan, žălosan i pridjeva izvorno n. p. c: bölesan, slöbodan u n. p. A te svi imaju kratkosilazni naglasak na svim oblicima. U ostalim štokavskim govorima kod višesložne stare n. p. $a$ i n. p. $c$ ujednačava se ili n. p. A ili n. p. C. Primjerice, u govoru Prapatnica (Kapović 2011: 383) pridjev bölesan - bolèsna - bölesno, a tako i pridjevi pâmetan, släbodan, žălosan dijelom su n. p. C, dok u govorima Imotske krajine i Bekije (Šimundić 1971: 128) pridjevi bolestan, radostan, slobodan, žalostan mogu biti dijelom n. p. A ili n. p. C. U govorima Makarskoga primorja Kurtović Budja (2009: 133) bilježi n. p. $C$ za pridjeve bölesān, rầdosān, žălosān, a u govoru su Bitelića pridjevi pầmetan, râdosan, žälosan, bölesan, slöbodan dijelom n. p. A (Ćurković 2014: 180).

U n. p. B ovjereni su samo pridjevi s dugim korijenom i to samo tip s dugouzlaznim naglaskom: smjéšan - smjéšna - smjéšno (SR)/smjéšan - smjéšna - smjéšno (Mi)/smišan smíšna - smíšno (Bl, Po). Iznimka je samo pridjev srètan koji ima n. p. B/C. U toj su paradigmi relativno dobro očuvani oblici stare n. p. b: bjédan, dúžan, míran, mútan, prázan, rávan, smjéšan, stídan, trjézan. U Imotskoj i Vrgorskoj krajini dolazi do miješanih tipova naglasnih paradigama, rijetki pridjevi koji su pripadali n. p. $b$ ostaju n. p. B, a sve

12 Više o pravilima kraćenja cirkumfleksa vidi u Kapović (2011: 376-377). 
je češća tendencija prevladavanja n. p. C (Kapović 2011: 398). Kod pridjeva grêšan koji je pripadao n. p. $b$ došlo je do sekundarnoga kraćenja i prelaska u n. p. C.

Razvidno je da se kod pridjeva s dugim korijenom u svim slivanjskim govorima gubi stara n. p. c, odnosno u m. r. umjesto dugosilaznoga naglaska ostvaruje se dugouzlazni, primjerice: ládan - ládna - lâdno. Takve smo pridjeve stoga svrstali u n. p. $C_{1}$. Iznimno je u jednome primjeru u govoru Podgradine i Mihalja ovjereno supostojanje paradigama glâdan - gládna - glâdno/gládan - gládna - glâdno. Budući da se u slivanjskim govorima u dugim pridjevima nije zadržala opreka između n. p. $b$ i n. p. $c$, analogijom prema n. p. B neki pridjevi u nju prelaze iz n. p. c: búdan, kívan, másan, rúžan, strášan, zlátan, dok pridjevi túžan i vrjédan u govoru Slivna Ravnoga mogu ići i po n. p. $C_{1}$ : túžan - túžna - túžno/tûžno; vrjédan - vrjédna - vrjédno/vrjêdno. Obrnuta je pojava izrazito rijetka, odnosno u n. p. $C_{1}$ samo je jedan pridjev iz n. p. b: žédan - žédna -žêdno.

Vidović (2014: 33) u zažapskim govorima bilježi čuvanje n. p. C u pridjeva: glâdan, tijêsan, stvâran, kao i Kurtović Budja (2009: 133) u govorima Makarskoga primorja: bîsan - bísna - bîsno, glâdan - gládna - glâdno, mâsan - másna - mâsno, lâdan - ládna lâdno, žêdan - žédna - žêdno itd. U mjesnome govoru Prapatnica (Kapović 2011: 413) uz nepromjenjivost paradigme: glâdan - gládna - glâdno, bîsan - bísna - bîsno, glâsan glásna - glâsno, mâsan - másna - mâsno, zlâtan - zlátna - zlâtno, može doći do prelaska u n. p. B: búdan - búdna - búdno ili do miješanja paradigma: lâdan/ládan - ládna - lâdno/ ládno. Šimundić (1971: 130-132) za govore Imotske krajine i Bekije donosi da pridjev ladan u m. r. glasi lâdan, dok je u ž. i sr. r. zabilježen uzlazni naglasak: ládna - ládno. Za pridjeve bisan, bolan, gladan, masan, tisan itd. ističe da postoje dvojni oblici, sa silaznim i uzlaznim naglaskom u m. i sr. r. Ćurković (2014: 181) pak u govoru Bitelića bilježi potpun prelazak u n. p. B: bísan, gládan, ládan, másan, zlátan.

\subsection{Pridjevi na -ak ( $\left.{ }^{*}-\mathbf{b} \mathbf{k}\right)$}

Naglasna paradigma $C$

\begin{tabular}{|l|c|c|c|}
\hline \multicolumn{1}{|c|}{ n. p. C } & m. . & ž. . & sr. $r$. \\
\hline Slivno Ravno & glädak & glàtka & glätko \\
\hline Mihalj & krâtak & krátka & krâtko \\
\hline Blace & pìtak & pìtka & pìtko \\
\hline Podgradina & špôrak & špórka & špôrko \\
\hline
\end{tabular}

SR n. p. C: blìzak, dr̃zak, dügačak, glädak, krâtak, krêpak, nìzak, pïtak, plïtak, sklìzak, slädak, tänak, üzak, vìtak

Mi n. p. C: dügačak, krâtak, nìzak, plìtak, slädak, tänak, üzak, vìtak

Bl n. p. C: blìzak, glädak, krâtak, nìzak, pìtak, plìtak, rítak, slädak, tânak, üzak

Po n. p. C: dügačak, krâtak, nìzak, pìtak, plìtak, slädak, špôrak 'prljav', tânak, üzak 
Naglasna paradigma $C_{1}$

\begin{tabular}{|l|c|c|c|}
\hline \multicolumn{1}{|c|}{ n. p. $\mathbf{C}_{1}$} & m. $\mathbf{r}$. & ž. $\mathbf{r}$. & sr. . \\
\hline Slivno Ravno & górak & górka & gôrko \\
\hline Mihalj & téžak & téška & têško \\
\hline Blace/Podgradina & rítak & rítka & rîtko \\
\hline
\end{tabular}

SR n.p. C 1 : górak, rjétak, téžak

Mi n. p. C 1 :górak, rijétak, téžak

Bl, Po n. p. C 1 : górak, rítak, téžak

U slivanjskim govorima nije pronađena n. p. A ni n. p. B, nego su svi pridjevi dijelom n. p. C. Kod pridjeva sa starom dugom n. p. c dolazi do kraćenja te ujednačavanja prema n. p. A iz koje zatim dolazi do prelaska u n. p. C, primjerice slàdak - slàtka - slätko, dr̈zak - driska-dr̈sko, krêpak - krèpka - krềpko.

Isto tako, i pridjevi sa starom dugom n. p. $b$ pokratili su se i postali dijelom n. p. C. primjerice üzak - ùska - ùsko, blìzak - blìska - blìsko, nìzak - nìska - nïsko. Kod pridjeva $k_{r a t a k^{13}}$ sačuvan je dugi odraz: krâtak - krátka - krâtko, dok je kod pridjeva rjétak (SR)/ rijétak (Mi)/rítak (Bl, Po) došlo do poopćenja naglasaka iz izvornoga oblika m. r., a u ž. i sr. r. ostvaruje se naglasak n. p. $C$ te taj pridjev postaje dijelom n. p. $C_{1}$.

I u ostalim su štokavskim govorima zabilježeni slični prelasci. Vidović (2007: 209) navodi da pridjevi nìzak, ùzak u govorima Dobranja i Vidonja u Neretvanskoj krajini pripadaju n. p. C, dok pridjev kratak ostaje u n. p. B (Vidović 2014: 33). Kurtović Budja (2009: 132-133) za n. p. C u govorima Makarskoga primorja navodi primjere: krötak, gïbak, glädak, nìzak, mř̀zak, slädak, krìpan. Šimundić (1971: 127) nalazi da pridjevi gibak, gladak, žitak, kratak, krotak, tanak, sladak, vitak u govorima Imotske krajine i Bekije prelaze u n. p. C. Kapović (2011: 421) donosi da u mjesnome govoru Prapatnica svi pridjevi također prelaze iz n. p. A u n. p. C: glädak, krìpak, pìtak, slädak, vìtak, nî̀zak, üzak. I u govoru Bitelića pridjevi: gïbak, glädak, krôtak, mř̀zak, nìzak, slädak dijelom su n. p. C (Ćurković 2014: 183).

Pridjevi gorak, tanak pripadali su n. p. c s izvornim kratkim vokalom, a pridjev težak izvorno je dug. U slivanjskim govorima pridjev tânak ostao je kratak i u n. p. C tânak - tánka - tânko, dok su se pridjevi górak i téžak produžili u mlađi dugouzlazni naglasak te prešli u n. p. $C_{1}$.

$\mathrm{U}$ ostalim je novoštokavskim govorima raznovrsna situacija. Tako primjerice $\mathrm{u}$ govorima Imotske krajine i Bekije ujednačena dužina (Šimundić 1971: 130-130) dolazi kod pridjeva: gorak, plitak, težak, kao i u govorima Makarskoga primorja (Kurtović Budja 2009: 132): gôrak, plitak, têžak (n. p. C), uz kračinu u tänak (n. p. C). U mjesnome govoru Prapatnica (Kapović 2011: 434) dužina je potvrđena u pridjevu têžak, a kračina u pridjevima gôrak i tânak. Ćuković $(2014:$ 181, 183) u govoru Bitelića bilježi prelazak pridjeva górak i téžak u n. p. B, dok pridjev tänak ostaje kratak i u n. p. C.

13 O naglasnim varijacijama pridjeva kratak u novoštokavskim govorima v. Kapović 2015: 21. 


\subsection{Pridjevi na -ar ( ${ }^{*}$-rb)}

Naglasna paradigma B

\begin{tabular}{|c|c|c|c|}
\hline n. p. B & m. . & ž. $\mathbf{r}$. & sr. $\mathbf{~}$. \\
\hline $\mathrm{SR}, \mathrm{Mi}, \mathrm{Bl}, \mathrm{Po}$ & döbar & dòbra & dòbro \\
\hline
\end{tabular}

SR n. p. B: bìstar (i n. p. C), döbar, ïtar 'hitar'

Mi n. p. B: bìstar, döbar

Bl n. p. B: döbar, ïtar, mödar (i n. p. C)

Po n. p. B: döbar (i n. p. C), ïtar (i n. p. C)

Naglasna paradigma $C$

\begin{tabular}{|c|c|c|c|}
\hline n. p. C & m. . & ž. . & sr. $r$. \\
\hline SR, Mi, Bl, Po & mökar & mòkra & mökro \\
\hline
\end{tabular}

SR n. p. C: bìstar (i n. p. B), mödar, mökar, ôštar, vềdar

Mi n. p. C: ïtar, mödar, mökar, öštar, vềdar

Bl n. p. C: bïstar, mồar (i n. p. B), mökar, öštar, vềdar

Po n. p. C: bïstar, döbar (i n. p. B), ïtar (i n. p. B), mödar, mökar, öštar, vêdar

Naglasna paradigma $C_{1}$

\begin{tabular}{|c|c|c|c|}
\hline n. p. $\boldsymbol{C}_{1}$ & m. . & ž. . & sr. $\boldsymbol{r}$. \\
\hline SR, Mi, Bl, Po & múdar & múdra & mûdro \\
\hline
\end{tabular}

SR, Mi, Bl, Po n. p. $C_{1}$ : hrábar, múdar

Pridjevi na ${ }^{*}$-rь u praslavenskome su imali ili n. p. $a$ ili n. p. $b$. Promotrimo li primjere iz slivanjskih govora razvidno je da je sinkronijsko stanje drukčije, točnije da pridjevi mogu pripadati n. p. B, n. p. C i iznimno n. p. $C_{1}$ Kolebanja su zabilježena kod pridjeva bìstar koji u govoru Slivna Ravnoga može imati oblike n. p. B i n. p. C, pridjeva mödar koji u govoru Blaca također pripada n. p. B i n. p. C te kod pridjeva döbar i ïtar u govoru Podgradine, s jednakim dvostrukostima. Vrlo je vjerojatno da su se pridjevi n. p. $a$ i n. p. $b$ stopili u sinkronijsku n. p. A iz koje naknadno prelaze u n. p. B i n. p. C.

Među Vidovićevim (2007: 209) podatcima za govore Dobranja i Vidonja nalazimo tek jedan pridjev koji završava na -ar: döbar, i on ima oblike n. p. B. U govorima Makarskoga primorja Kurtović Budja (2009: 133) donosi nekoliko primjera pridjeva koji završavaju na -ar te je pridjev mödār - mòdra - mòdro dijelom n. p. B, a pridjevi mökar mòkra - mökro, vềdar - vèdra - vêdro, öštar - òštra - öštro n. p. C. Šimundić (1971: 127) navodi da samo pridjev öštar u govorima imotskoga kraja može ostati u n. p. A ili prijeći u n. p. C, dok pridjevi modar, mokar, vedar prelaze u n. p. C. Ćurković $(2014: 182,183)$ u govoru Bitelića bilježi da pridjevi döbar i mödar pripadaju n. p. B, a pridjev vêdar n. p. C. To 
nam potvrđuje činjenicu utvrđenu našim istraživanjem da pridjevi na -ar, prema dosadašnjim podatcima, nemaju očuvanu sinkronijsku n. p. A.

\subsection{Pridjevi na -al (*-lb)}

Naglasna paradigma $B$

\begin{tabular}{|l|c|c|c|}
\hline \multicolumn{1}{|c|}{ n. p. B } & m. $\mathbf{r}$. & ž. $\mathbf{~}$ & sr. . \\
\hline $\mathrm{SR}, \mathrm{Mi}, \mathrm{Bl}$ & nágal & nágla & náglo \\
\hline Po & nágā & nágla & náglo \\
\hline Po & okrúgā & okrúgla & okrúglo \\
\hline
\end{tabular}

SR, Mi, Bl n. p. B: nágal

Po n. p. B: nágā, okrúgā

Naglasna paradigma $C$

\begin{tabular}{|c|c|c|c|}
\hline n. p. C & m. $\mathbf{r}$. & ž. $\mathbf{r}$. & sr. $\mathbf{r}$. \\
\hline SR, Mi, Bl, Po & töpāl & tòpla & töplo \\
\hline
\end{tabular}

SR, Mi, Bl, Po n. p. C: ôbal, tồpāl

I pridjevi na ${ }^{*}$-lъ u praslavenskome nisu imali pomičnu naglasnu paradigmu $c$, nego je pridjev pripadao ili n. p. $a$, ako je korijen bio akutiran, ili n. p. $b$, ako nije imao akuta. Danas je malo pridjeva s tim završetkom i malo potvrda o njima u radovima o novoštokavskim govorima.

U ekscerpiranoj građi nalazimo samo četiri potvrde: öbal, nágal (SR, Mi, Bl)/nágā (Po) tôpal i okrúgā (Po). Pridjevi nágal/nágā i okrúgā imaju oblike n. p. B, a pridjevi ôbal i tôpal oblike n. p. C. Za govore Makarskoga primorja i Kurtović Budja (2009: 133) bilježi n. p. C kod pridjeva tồāl - tòpla - tồlo, a Šimundić (1971: 130) u govorima Imotske krajine i Bekije uz n. p. A nâgā - nâgla - nâglo nalazi i n. p. C nágā-nágla-náglo. Ćurković (2014: 183) u govoru Bitelića bilježi samo n. p. C: öbal - òbla - ôblo, tôpal - tòpla - tôplo.

\subsection{Pridjevi na -en (*ęnъ, *-enъ-)}

Naglasna paradigma A

\begin{tabular}{|l|c|c|c|}
\hline \multicolumn{1}{|c|}{ n. p. $\mathbf{A}$} & m. $\mathbf{r}$. & ž. $\mathbf{r}$. & sr. $\mathbf{r}$. \\
\hline Slivno Ravno & lànen & lànena & làneno \\
\hline Mihalj & ràžen & ràžena & ràženo \\
\hline Blace & vàtren & vàtrena & vàtreno \\
\hline Podgradina & vùnen & vùnena & vùneno \\
\hline
\end{tabular}

SR, Mi, Bl, Po n. p. A: càklen, lànen, lèden, mèden, ràžen, svìlen, vàtren, vòden, vùnen, zòben 
Naglasna paradigma $B$

\begin{tabular}{|l|c|c|c|}
\hline \multicolumn{1}{|c|}{ n. p. B } & m. $\mathbf{r}$. & ž. $\mathbf{r}$. & sr. $\mathbf{r}$. \\
\hline Slivno Ravno & cr̀vven & crvèna & crvèno \\
\hline Mihalj & pòšten & poštèna & poštèno \\
\hline Blace & rùmen & rumèna & rumèno \\
\hline Podgradina & šàren & šarèna & šarèno \\
\hline
\end{tabular}

SR, Mi, Bl, Po n. p. B: cr̀vven, màlen, pòšten, rùmen, stùden, šàren, zèlen

Pridjevi koji danas završavaju na -en nastali su od pridjeva koji su u praslavenskome završavali na ${ }^{*}$-ęnъ, *-enъ-, no budući da je to irelevantno za sinkronijsku obradu naglasnih paradigma, u radu ih nećemo razdvajati u posebne skupine.

Iz primjera je uočljivo da su potvrđene samo dvije naglasne paradigme: n. p. A i n. p. B. Vidljivo je i da svi gradivni pridjevi koji označavaju da je nešto izrađeno/napravljeno od nečega idu po oblicima n. p. A: râž > ràžen, zôb > zòben, càklo > càklen, vüna > vùnen, lân > lànen itd., a oni koji označuju boje po oblicima n. p. B: šàren - šarèna - šarèno.

Vidović (2013: 166) u govorima Dobranja i Vidonja od pridjeva koja završavaju na -en donosi samo one koji označuju boje: zèlen - zelèna - zelèno, cr̀ven - crvèna - crvèno, kàfen - kafèna - kafèno i oni su dijelom n. p. B, kao i u slivanjskim govorima. Šimundić (1971: 129-130) u govorima Imotske krajine i Bekije bilježi da pridjev càklen ima oblike n. p. B, vjerojano analogijom prema pridjevima crìven, zèlēn, màlen, pòsten, šàren, zèmljen, koji su u tim govorima dijelom n. p. B. I Ćurković (2014: 181) u govoru Bitelića bilježi da pridjevi crven - crvèna - crvèno, rùmen - rumèna - rumèno, zèlen - zelèna - zelèno pripadaju n. p. B.

\subsection{Pridjevi na -av $\left(^{*}\right.$-avb)}

Naglasna paradigma $A$

\begin{tabular}{|c|c|c|c|}
\hline n. p. A & m. r. & ž. r. & sr. r. \\
\hline Slivno Ravno & bälav & bälava & bälavo \\
\hline Mihalj & čìtav & čìtava & čìtavo \\
\hline Blace & trälav & träl̦ava & träl̦avo \\
\hline Podgradina & mütav & mütava & mütavo \\
\hline
\end{tabular}

SR, Mi, Bl n. p. A: bälav, blèsav, čàśav, čitav, čùpav, dläkav, gàrav, gr̆bav, gübav, kìlav,

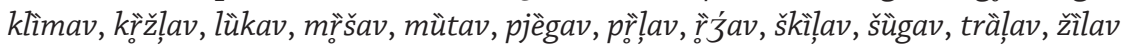

Po n. p. A: bälav, blësav, čầ̆av, ćìtav, cuùpav, dläkav, gärav, gr̂̀bav, gübav, kìlav, klî̀mav, kř̀vav, lükav, mřšav, mütav, ř̉̆̌av, škìjav, šügav, träjav, žĭlav 
Naglasna paradigma $C$

\begin{tabular}{|c|c|c|c|}
\hline n.p. C & m.r. & ž.r. & sr. r. \\
\hline SR, Mi, Bl & kr̂̀vav & krváva & kr̂̀vavo \\
\hline
\end{tabular}

SR, Mi, Bl n. p. C: krìvav

Kod pridjeva koji završavaju na -av u slivanjskim govorima nije zabilježena n. p. B. Prevladala je n. p. A sa stalnim naglaskom na osnovi. Možemo zaključiti da u toj paradigmi nema kolebanja, odnosno očekivano se ostvaruje kratkosilazni naglasak u svim primjerima, osim u pridjevu čitav (SR, Mi, Bl)/čitav (Po).

Govori Slivna Ravnoga, Mihalja i Blaca iznimno čuvaju polazni oblik n. p. c u pridjevu kr̂̀vav, dok je u govoru Podgradine zabilježen prelazak u n. p. A: kr̈vvav - krro vava - kr̂̀vavo, vjerojatno analogijom prema ostalim pridjevima, ali i pod utjecajem susjednih zapadnoštokavskih govora u kojima, kao i govorima Makarskoga primorja, nema potvrde za postojanje n. p. C kod pridjeva koji završavaju na -av.

U susjednim zažapskim govorima dulji se nastavak $-\bar{a} v$ i pridjev prelazi u n. p. B: kr̂̀vāv - krvàva - krvàvo (Vidović 2014: 33). Šimundić (1971: 128) bilježi da taj pridjev može biti dijelom n. p. A i n. p. C: kṛoāv - kṛ̂̀vāva/krváva - kr̆̀vāvo u govorima Imotske krajine i Bekije. Bošnjak Botica i Menac-Mihalić (2006: 38) u govoru Lovreća pokraj Imotskoga također bilježe sačuvanu n. p. C kod pridjeva kr̂̀vāv, uz napomenu da kod mlađih govornika prevladava oblik n. p. A. U Vrgorskoj pak krajini pridjev krvav pripada n. p. A (Kapović, usmeno).

\subsection{Pridjevi na -ok ${ }^{*}$-okb)}

Naglasna paradigma $B$

\begin{tabular}{|l|c|c|c|}
\hline \multicolumn{1}{|c|}{ n. p. B } & m. . & ž. . & sr. r. \\
\hline Slivno Ravno & dùbok & dubòka & dubòko \\
\hline Mihalj & š̀̀rok & širòka & širòko \\
\hline Blace & vìsok & visòka & visòko \\
\hline Podgradina & žèstok & žestòka & žestòko \\
\hline
\end{tabular}

SR, Mi, Bl, Po n. p. B: dùbok, šìrok, vissok, žèstok

U slivanjskim je govorima zabilježeno tek nekoliko pridjeva koji završavaju na -ok i svi pripadaju n. p. B, čime ti govori ne odstupaju od ostalih novoštokavskih govora u kojima je situacija identična.

Tako Vidović (2013: 166) u zažapskim govorima također nalazi da pridjevi dùbok, širok i visok imaju oblike n. p. B. Kurtović Budja (2009: 132) u govorima Makarskoga primorja pridjeve dùbok, šìrok ubraja u naglasni tip B, kao i Šimundić (1971: 129), s tim da u je govorima Imotske krajine potvrđena duljina: dùbōk, šìrōk, visōo. I u govoru Bitelića u Sinjskoj krajini pridjevi dùbok i vissok dijelom su n. p. B (Ćurković 2014: 181). 


\subsection{Ostali pridjevi}

Naglasna paradigma A

\begin{tabular}{|l|c|c|c|}
\hline \multicolumn{1}{|c|}{ n. p. A } & m. . & ž. . & sr. . \\
\hline Slivno Ravno & kìsevo & kìsela & kìselo \\
\hline Mihalj & mànit & mànita & mànito \\
\hline Blace & sìrov & sìrova & sìrovo \\
\hline Podgradina & vèsel & vèsela & vèselo \\
\hline
\end{tabular}

SR, Mi, Bl n. p. A: bògat, gòtov, kìsevo, gàdlivi, jèdnak, lägan, làžliv, mànit, màrḷiv, mëkān, milòstiv, öhol, pèrnat, pitom, pògan, sìrov, sr̀dit, stṛ̀pliv, vèlik, svàdlìv

Po n. p. A: bògat, gòtov, kìsel, gàdjiv, jèdnak, làgan, làžjiv, mànit, mëkān, milòstiv, mìntav, öhol, öpāk, pèrnat, pitom, pògan, sïrov, şrdit, str̀̀pjiv, vèlik, vêsel, svàdjiv

Naglasna paradigma $B$

\begin{tabular}{|l|c|c|c|}
\hline \multicolumn{1}{|c|}{ n. p. B } & m. $\mathbf{r}$. & ž. $\mathbf{r}$. & sr. . \\
\hline Slivno Ravno & dèbevo & debèla & debèlo \\
\hline Mihalj & mŕotav & mŕtva & mŕ́tvo \\
\hline Blace & dàlek & dalèka & dalèko \\
\hline Podgradina & šúpaj & šúpja & šúpje \\
\hline
\end{tabular}

$\mathrm{SR}, \mathrm{Mi}, \mathrm{Bl}$ n. p. B: dàlek, dèbevo, gòlem, mìtav, šúpal

Po n. p. B: dàlek, dèbel, gòlem, šúpaj

Naglasna paradigma $C$

\begin{tabular}{|c|c|c|c|}
\hline \multicolumn{1}{|c|}{ n. p. C } & m. $\mathbf{r}$. & ž. $\mathbf{r}$. & sr. $\mathbf{r}$. \\
\hline $\mathrm{SR}, \mathrm{Mi}, \mathrm{Bl}$ & òpāk & opáka & òpāko \\
\hline $\mathrm{SR}, \mathrm{Mi}, \mathrm{Bl}$ & vèsevo & vesèla & vèselo \\
\hline
\end{tabular}

SR, Mi, Bl n. p. C: òpāk, vêsevo

Na kraju ćemo prikazati i ostale pridjeve zabilježene u slivanjskim govorima. Iz prikazanih podataka vidljivo je da prevladavaju oblici n. p. A. U govorima Slivna Ravnoga, Mihalja i Blaca zabilježene su sve tri paradigme, a u govoru Podgradine samo n. p. A i n. p. B.

Pridjev dèbevo (SR, Mi, Bl)/dèbel (Po) ostao je dijelom n. p. B, kako je i u drugim štokavskim govorima, primjerice u zažapskim govorima, oblikom dèbel (Vidović 2013: 166), u govorima Makarskoga primorja (Kurtović Budja 2009: 132), s oblikom dèbejā debèla - debèlo, u govorima Badnja, Omiša, Sinja, Koteza (ikavskim govorima od Krke do Neretve) (Celinić i dr. 2010: 188), u govoru Bitelića u Sinjskoj krajini, s oblicima dèbēl dèbel - debèla - debèlo (Ćurković 2014: 181), dok u govorima Imotske krajine i Bekije (Šimundić 1971: 129) pridjev dèbejo može imati i n. p. A: dèbejo - dèbela - dèbelo. I za 
pridjev dàlek u ostalim štokavskim govorima nalazimo n. p. B. Tako je primjerice u zažapskim govorima (Vidović 2007: 209), govorima Makarskoga primorja (Kurtović Budja 2009: 132), u govoru Bitelića (Ćurković 2014: 181), te u govorima Imotske krajine i Bekije (Šimundić 1971: 129), ali uz duljenje: dàlēk. Zanimljivo je da je u govorima Slivna Ravnoga, Mihalja i Blaca dužina, koja je i očekivana prema psl. *mьr̃tvъ, očuvana u pridjevu mŕtav, dok u Podgradini bilježimo mr̀tav.

U govorima Slivna Ravnoga, Mihalja i Blaca u n. p. C ostaju pridjevi òpāk, vêsevo, dok pridjev jèdnak prelazi u n. p. A. U nekim se govorima pridjev jednak očuvao u n. p. C. Staro je stanje zabilježeno u govoru Lovreća (Bošnjak Botica i Menac-Mihalić 2006: 38), dok u govoru mlađe populacije prevladava oblik n. p. C, čime se ti podatci podudaraju sa Šimundićevima (1971: 128) koji je zabilježio da u govorima Imotske krajine supostoje oblici n. p. A i n. p. C.

U govorima Makarskoga primorja pridjev vesel prešao je u n. p. A: vêsejā - vềsela vêselo, kako je i u govoru Bitelića u Sinskoj kraini zabilježila Ćurković (2014: 179), s oblicima vêsē/vêsel - vêsela - vêselo, dok u govorima Imotske krajine (Šimundić 1971: 127-128) pridjev vesejo može imati oblike n. p. A i n. p. C.

\section{Zaključak}

U svim je slivanjskim govorima ovjerena kategorija 'određenost'/'neodređenost' u $\mathrm{N}$ jd. pridjeva svih triju rodova. Specifičnost je sklonidbe neodređenih i određenih pridjeva promjena $-\bar{o} j>-\bar{o} n \mathrm{u} \mathrm{D} / \mathrm{L}$ jd. ž. r., koja čini unutarnju diferencijaciju slivanjskih i zažapskih govora, u kojima je pak ta promjena marginalna. Kod određenih pridjeva tvrde osnove u govorima Slivna Ravnoga i Mihalja potvrđeni su i nastavci starih tvrdih osnova u I jd. m. i sr. r. -ijēe(n), G mn. -ijē i D/L/I mn. -ijēe(n) m., s. r. i ž. r.

U slivanjskim se govorima kod korijenskih pridjeva ne razlikuju stara n. p. $a$ i n. p. $b$, nego su uglavnom pridjevi postali dijelom n. p. C: läk - làka - läko, što slivanjske govore povezuje s govorima Makarske i Vrgorske krajine. U svim je govorima dobro očuvana izvorna n. p. c kod pridjeva tipa glûv - glúva - glûvo i mốcan - mòćna - mồ́no (SR, Mi, Bl)/ möčan - mòčna - möčno (Po), kao i kod pridjeva ôpāk, vêsevo i kr̂̀vav. Jedinu inovaciju primjećujemo u pridjeva s dugim korijenom koji završavaju na -an: ládan - ládna - lâdno, kod kojih se izvorni dugosilazni naglasak u m. r. mijenja u dugouzlazni te oni postaju n. p. $C_{1}$ ili pak prelaze u n. p. B: rúžan - rúžna - rúžno. Kod pridjeva koji završavaju na -an očuvani su oblici stare n. p. $b$ : dúžan - dúžna - dúžno, što slivanjske govore odvaja od vrgorskih i imotskih, u kojima dolazi do miješanih paradigama i prevladavanja n. p. C. Svi pridjevi koji označavaju boje, bilo korijenski: žût - žúta - žúto, bilo oni sa sufiksom -en: zèlen - zelèna - zelèno čuvaju n. p. B, kako je i u ostalim ijekavskim zažapskim govorima te ikavskim govorima Makarske, Vrgorske i Sinjske krajine. 


\section{Literatura}

Benić, Mislav (2013) Opis govora Kukljice, doktorska disertacija, Filozofski fakultet Sveučilišta u Zagrebu.

Bošnjak Botica, Tomislava, Mira Menac-Mihalić (2006) „Vokalizam i akcentuacija govora Lovreća", Rasprave Instituta za hrvatski jezik i jezikoslovlje, 32, 25-41.

Gudek, Vedrana (2013) Opis govora Gornje Konjščine, diplomski rad, Filozofski fakultet Sveučilišta u Zagrebu.

Celinić, Anita i dr. (2010) Prinosi hrvatskoj dijalektnoj fonologiji, Književni krug Split Institut za hrvatski jezik i jezikoslovlje, Split - Zagreb.

Crnić Novosel, Mirjana (2015) Štokavski ikavski govori u Gorskome kotaru (fonološki i morfološki aspekt), doktorska disertacija, Filozofski fakultet Sveučilišta u Rijeci.

Ćurković, Dijana (2014) Govor Bitelića, doktorska disertacija, Filozofski fakultet Sveučilišta u Rijeci.

Halilović, Senahid (1996) Govorni tipovi u međuriječju Neretve i Rijeke dubrovačke, Bosanskohercegovački dijalektološki zbornik 7, Institut za jezik, Sarajevo.

Kapović, Mate (2011) „Historical Development of Adjective Accentuation in Croatian (suffixless, *-ьnъ and *-ъkъ adjectives)", Baltistica, VII, 103-448.

Kapović, Mate (2015) Povijest hrvatske akcentuacije. Fonetika, Matica hrvatska, Zagreb.

Kurtović Budja, Ivana (2009) Govori Makarskoga primorja (fonologija i morfologija), doktorska disertacija, Filozofski fakultet Sveučilišta u Zagrebu.

Šimundić, Mate (1971) Govor Imotske krajine i Bekije, ANUBiH, Sarajevo.

Vidović, Domagoj (2007) „Accentual alternations in Neo-Štokavian Ijekavian Dialects of Neretvanska Krajina", Tones and Theories: Proceedings of the International Workshop on Balto-Slavic Accentuation, ur. Mate Kapović i Ranko Matasović, Zagreb, 199-211.

Vidović, Domagoj (2013) „Naglasci u govorima i toponimiji Zažablja i Popova”, Rasprave Instituta za hrvatski jezik i jezikoslovlje, 39, 1, 155-173.

Vidović, Domagoj (2014) Zažapska onomastika, Institut za hrvatski jezik i jezikoslovlje, Zagreb.

Vukša Nahod, Perina (2014) „O slivanjskome području i o slivanjskim govorima”, Petar Tutavac Bilić: hrvatski publicist, književnik, jezikoslovac i prevoditelj, ur. Stjepan Šešelj, Zagreb, 13-27.

Vukša Nahod, Perina (2015a) „Naglasak imenica e-vrste i i-vrste u slivanjskim govorima”, Rasprave: Časopis Instituta za hrvatski jezik i jezikoslovlje, 41, 1, 163-186.

Vukša Nahod, Perina (2015b) „Valja nama preko rijeke/rike - iz fonologije mjesnoga govora Podgradine u Neretvanskoj dolini”, Rasprave: Časopis Instituta za hrvatski jezik i jezikoslovlje, 41, 1, 393-423. 


\section{SUMMARY}

\section{Perina Vukša Nahod}

\section{ACCENT PARADIGMS OF ADJECTIVES IN THE SLIVNO MUNICIPALITY}

This paper is based on materials gathered in the field and provides a synchronic overview of the accent paradigms of adjectives in the Slivno municipality speech varieties found in Slivno Ravno, Mihalj, Blace and Podgradina. These speeches belong to the Eastern Herzegovinian border dialect and the Slivno-Zažablje speech type. Furthermore, accent variations in the other explored Štokavian speeches will be determined. Root (suffix-less) adjectives in the Slivno municipality speech varieties do not show the old a. p. $a$ and a. p. $b$, but are mostly formed as a part of the a. p. C: läk - làka - läko 'easy', which connects these speech varieties with the Makarska and Vrgorac municipality speech varieties. All the speeches have well preserved authentic a. p. $c$ in adjectives such as glûv - glúva - glûvo 'deaf' and möćan - mòćna - môćno 'mighty' (SR, $\mathrm{Mi}, \mathrm{Bl})$ / môćan - mòćna - mồno (Po), and in adjectives such as ôpāk 'tough', vèsevo 'happy' and kr̂̀vav 'bloody'. The only innovation is found in adjectives with a long root ending in -an: ládan - ládna - lâdno 'cold', where the authentic long falling accent in $\mathrm{m}$. changes into the long rising one, thus becoming a. p. $\mathrm{C}_{1}$, or it changes to a. p. B: rúžan - rúžna - rúžno 'ugly'. Adjectives ending in -an have preserved the form

of the old a. p. b: dúžan - dúžna - dúžno 'indebted', which distinguishes the Slivno municipality speech varieties from those of Vrgorac and Imotski where paradigms are mixed and where the a. p. C prevails. All adjectives referring to colour, whether they are suffix-less (root): žût - žúta - žúto 'yellow' or whether they end in the suffix -en: zèlen - zelèna - zelèn 'green', have a. p. B. just like the other Ijekavian speech varieties of the Zažablje municipality and the Ikavian varieties of the Makarska, Vrgorac and Sinj municipalities.

Key words: Štokavian dialect; Slivno-Zažablje speech type; adjectives; accent paradigms 